\title{
INHIBITORY EFFECT OF AQUEOUS LEAF EXTRACT OF Parthenium hysterophorus L. ON SEED GERMINATION AND SEEDLING GROWTH OF SOME CULTIVATED CROPS
}

\author{
AWANISH KUMAR SINGH ${ }^{1}$ \\ Department of Botany, S.G.N. Govt. P.G. College Muhammadabad, Gohna, Mau, Uttar Pradesh, India
}

\begin{abstract}
Allelopathic effect of Parthenium hysterophorus L. was studied on seed germination and seedling growth of two cereles crops (Triticum aestivum L. and Zea mays L.) and one pulse crop (Vigna radiata (L.) R. Wilczek). The existences of allelopathlc effect of weeds in oilseeds and legumes have been reported by various workers. But the magnitude of effects varies with the weed species. Aqueous leaf extracts of Parthenium hysterophorus L. caused significant reduction in germination of seeds, shoot and root length of Triticum aestivum L.,Zea mays L. and Vigna radiata (L.) R. Wilczek. The Zea mays $\mathbf{L}$. were more sensitive to inhibitory effects of the leaf extract of Parthenium hysterophorus $\mathrm{L}$. at $5 \%$ concentration of both seed germination and seedlings. Seed germination of maize was inhibited at $2 \%$ leaf extract of Parthenium hysterophorus but other crops like wheat and green gram, failure of seed germination was recorded only at $5 \%$ concentration of leaf extract. The seed germination, plumule and radicle length were reduced with increasing concentration of aqueous solution. The study concluded that increasing concentration of leaf extract of Parthenium hysterophorus has adverse effect on germination, shoot length, and root length and biomass production of Zea mays followed by Triticum aestivum and Vigna radiata than the control.
\end{abstract}

KEYWORDS: Allwlopathy, Germination, Seedlings Length, Parthenium hysterophorus, Zea mays

Allelopathy concerns the effects of one plant on another due to biochemicals released by them, or the breakdown products of their metabolites (Willis, 1994). Parthenium hysterophorus L. is an aggressive weed having allelopathic effect and drastically retards the growth of many crop species. In India parthenium was found to invade the agriculture lands of sugarcane, rice (Singh et al., 2005) and inhibit the growth of pasture grasses, legumes, cereals, vegetables, forage crops, pulses, oil seeds other weeds and trees. Parthenium is considered as a noxious weed due to its allelopathic chemicals. The chemical analysis of parthenium contains coronopilin, tetraneurin A, 2 $\beta$-hydroxycoronopilin, hysterones A-D, parthenin and acetylated pseudoguaianolides. These allelochemicals significantly decrease the seed germination and subsequent growth in many crops (Batish et al., 2005), by affecting carbohydrate, protein metabolism, physiological changes such as cellular membrane damage, chromosomal aberrations, chlorophyll loss in leaves and loss of dehydrogenase activity in roots of green gram (Rajendiran, 2005).

Parthenium hysterophous L. is native to tropical and subtropical America. This plant species is very invasive invader in large extent and it is threatened grassland ecosystem of Australia and India. This weed possesses many hazardous substances and it is very harmful to the surrounding flora, animals and also to human health. It has been already invaded in most of the useful field areas in urban and village. To explore allelopathic potential of Parthenium hysterophorus L. we have studied the effect of aqueous extract of leaves using different concentrations on seed germination and seedling growth of threecultivated crop species. The Parthenium hysterophorus L. is growing together with these crops and it is more common and dominant plant species.

From this strong reason the allelopathy on crop seed was experimented to study the effect of different concentrations of parthenium on seed germination of cereals and pulse crops, to know the variation in plumule length and radicle length of crop seeds by parthenium allelopathy, the impact of allelopathy on drymatter production in different crops and to assess the impact of Parthenium allelopathy on cereals and pulse crop.

\section{MATERIALS AND METHODS}

The Parthenium hysterophorus plant samples were collected at flowering stage. The leaves were separated, cut into fine pieces and dried in shade, finely made powder using Mixer grinder. Ten gram of leaf powder was taken in Soxhlet extraction apparatus and extracted in distilled water for six hours. Finely this extract was evaporated and stored in refrigerator for further experiments. 


\section{Bioassay}

Different concentrations of aqueous extract of Parthenium hysterophorus L. (2 and 5\%) were made.Ten uniform seeds of wheat were placed equidistantly in 10 $\mathrm{cm}$ dia.petriplates fitted with two layers of filter paper. 15 $\mathrm{ml}$ of 2 and $5 \%$ extracts of P.hysterophorus L. were added into the Petri-dishes as per treatments. Sterilized water was used as control. The treatments were replicated five times in complete randomized design. The Petridishes were maintained under laboratory condition for 7 days. Equal volume of distilled water was added in the dishes when moisture content of the blotting paper declined. After 7 days number of germinated seeds were counted and the root and shoot length were measured. The data were analyzed statistically using critical difference at $5 \%$ level of significance.

Same procedure was followed to evaluate allelopathic effects of Parthenium hysterophorus L. on seed germination and seedling emergence of other selected crop plant i.e. Zea mays (L)., and Vigna radiata wilczek.

\section{RESULTS AND DISCUSSION}

\section{Germination Percentage}

The parthenium extract effect on crops showed that the concentrations of Parthenium significantly affected the germination of all the test species. As concentration of plant extract increases, the percentages of seed germination get inhibited as compared to control in all the three crop species (Table 1). There were maximum inhibitions in $5 \%$ aqueous extract in Zea mays L. followed by Vigna radiata then Triticum aestivum. The lowest seed germination percentage in Zea mays (58\%) and higest germination percentage in Triticum aestivum $(74 \%)$ at $5 \%$ concentration of leaf extact.

Table 1: Effect of aqueous leaf extract of Parthenium hysterophorus on germination percentage of different crops

\begin{tabular}{|c|c|c|c|}
\hline Treatment & $\begin{array}{c}\text { Triticum } \\
\text { aestivum }\end{array}$ & Zea mays & $\begin{array}{c}\text { Vigna } \\
\text { radiata }\end{array}$ \\
\hline 0(Control) & 96.0 & 96.0 & 96.0 \\
\hline $2 \%$ & 86.0 & 70.0 & 84.0 \\
\hline $5 \%$ & 74.0 & 58.0 & 72.0 \\
\hline C.D. at 5\% & 19.55 & 18.03 & 19.23 \\
\hline
\end{tabular}

In this study, the reduction in seed germination was observed with increasing concentration of aqueous extract of parthenium in Zea mays. But in case of Triticum aestivum and Vigna radiata reduction in germination percentage was less with increase in concentration. The similar results on germination of seed were recorded in the Brassica species (Singh et al., 2005; Rashid et al., 2008), Triticum species (Dongre and Singh 2007) and Phaseolus species (Dongre et al., 2004) by increase of parthenium concentration.

\section{Seedling Growth}

The effect of aqueous extracts of Parthenium hysterophorus L. were examined for root, shoot and total length growth and results are summarized in Table 2. Among all the plant species the concentration of extract increases the root and the shoot length reduces as compare to control. The maximum decrease in root length was recorded in Maize $(3.8 \mathrm{~cm})$ followed by Green gram $(6.8 \mathrm{~cm})$ and the least by Wheat $(7.1 \mathrm{~cm})$ in $5 \%$ concentration. The reduction in radicle length was observed in all the test crops with increasing concentration of extracts. Similar effect of leaf aqueous extract of Parthenium hysterophorus was reported in cereals (Regina et al., 2007; Rashid et al., 2008; Dongre et al., 2010).

Different concentrations of Parthenium had significant effects on shoot length of cereals and pulses. Seedling length of maize and wheat was significantly decreased with the increase in concentration of Parthenium extracts from 0 to $2 \%$. The similar trend was observed in green gram but the slight decrease in the seedling length. The reduction in shoot length is observed in Maize $(35.4 \mathrm{~cm})$ in $5 \%$ concentration followed by Wheat $(31.3 \mathrm{~cm})$ and lowest by Green gram $(25.2 \mathrm{~cm})$. Higher concentration of Parthenium retard the growth of plants which might be due to inhibition of cell division as allelopathic chemicals have been found to inhibit gibberellin and indole acetic acid function (Tomaszewski \& Thimann, 1966) which causes reduced plumule length.

Among the plumule and radicle length, the radicle length trend showed a rapid reduction than the plumule length in all the crops (Figure 1). Because the radicle had more area of root surface exposed to the allelochemical. The strong inhibitory effects of Parthenium hysterophorus on root elongation might be due to direct contact of root than the shoot with the extract and subsequently with inhibitory chemicals with various crops and weeds (Quasem 1995) (Table 2). 
SINGH: INHIBITORY EFFECT OF AQUEOUS LEAF EXTRACT OF Parthenium hysterophorus L. ON SEED....

Table 2: Effect of aqueous leaf extract of Parthenium hysterophorus on seedlings growth of different crops

\begin{tabular}{|c|c|c|c|c|}
\hline Crop & Treatment & Root length $(\mathrm{cm})$ & Shoot length $(\mathrm{cm})$ & Total length $(\mathrm{cm})$ \\
\hline \multirow{4}{*}{ Triticum aestivum } & $0($ Control $)$ & 11.3 & 45.1 & 56.4 \\
\cline { 2 - 5 } & 2 & 8.4 & 34.2 & 42.4 \\
\cline { 2 - 5 } & 5 & 7.1 & 31.3 & 38.4 \\
\cline { 2 - 5 } & CD at 5\% & 0.22 & 0.17 & 0.39 \\
\hline \multirow{5}{*}{ Zea mays } & $0($ Control $)$ & 6.28 & 68.4 & 74.6 \\
\cline { 2 - 5 } & 2 & 4.68 & 49.8 & 54.5 \\
\cline { 2 - 5 } & 5 & 3.82 & 35.4 & 39.2 \\
\cline { 2 - 5 } & CD at 5\% & 1.16 & 13.04 & 14.2 \\
\hline \multirow{5}{*}{ Vigna radiata } & $0($ Control) & 8.2 & 32.2 & 40.4 \\
\cline { 2 - 5 } & 2 & 7.6 & 26.3 & 13.9 \\
\cline { 2 - 5 } & 5 & 6.8 & 25.2 & 32.1 \\
\cline { 2 - 5 } & CD at 5\% & 0.20 & 0.70 & 0.40 \\
\hline
\end{tabular}

Some earlier work have also reported that the Parthenium hysterophorus L. reduces root and shoot length of Zea mays L. and Glycine max L. (Bhatt et al., 1994). Due to the presence of allelochemicals in aqueous extract of Parthenium hysterophorus L. showing inhibitory effect on different plant species (Rajan, 1973). This plant releases the number of allelochemicals to surround such as phenolic acids, sesquiterpene lactones especially parthenin (Kanchan, 1975, Swminathan et al., 1990). Studies also shown that the phenolics compounds found in leaf of Parthenium hysterophorus L. have inhibitory effect on nitrogen fixing and nitrifying bacteria (Kanchan and Jayachandra 1979). The study demonstrated that leaf extract of Parthenium hysterophorus L. exhibited significant inhibitory effects on seed germination and seedling growth in selected plant species.

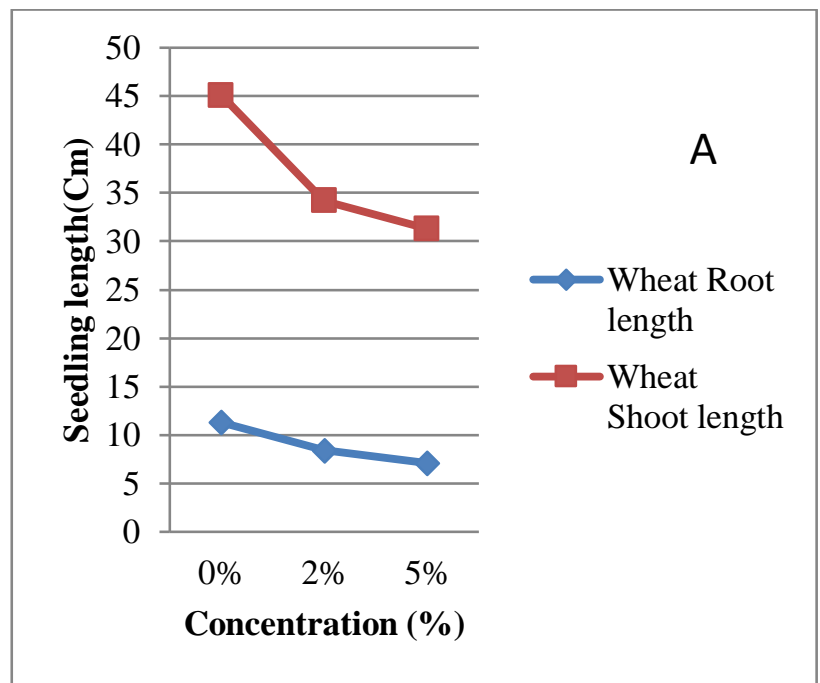

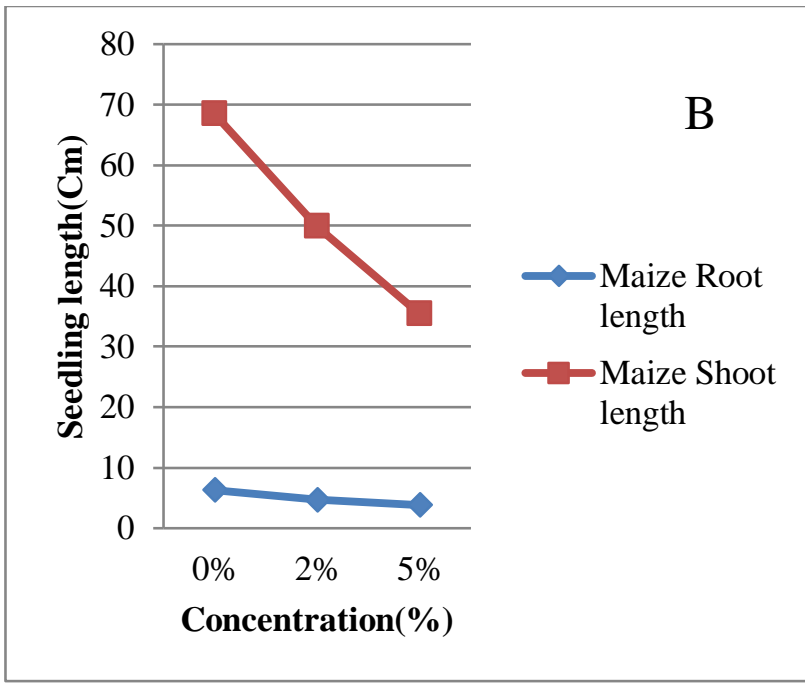

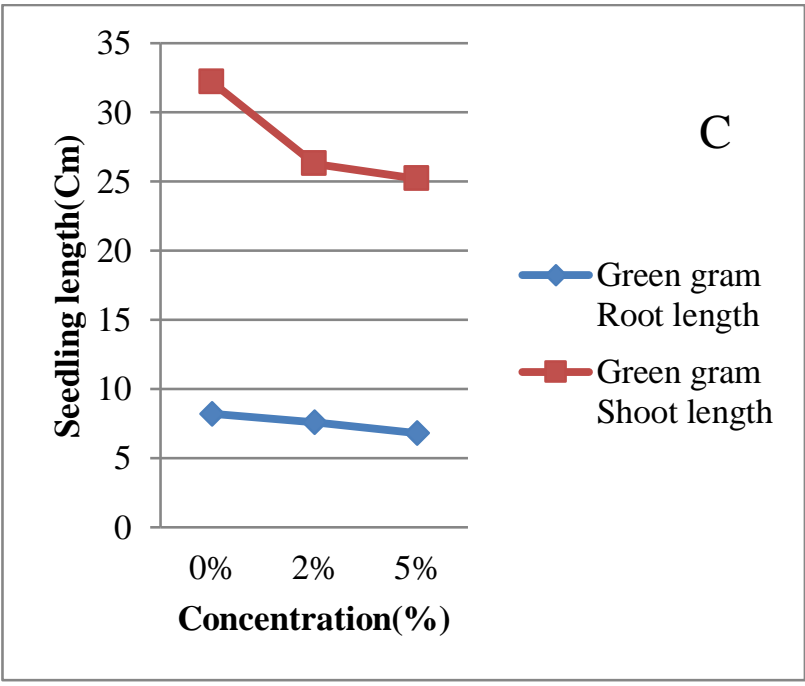

Figure 1: Allelopathy effect of Parthenium on Shoot length and Root length of Wheat (A), Maize (B) and Green gram $(C)$ 


\section{CONCLUSION}

The Zea mays L. were more sensitive to inhibitory effects of the leaf extract of Parthenium hysterophorus L. at $5 \%$ concentration of both seed germination and seedlings. The leaf extract has inhibitory effect on radical growth of cereals compare to pulses seeds. Seed germination of maize was inhibited at $2 \%$ leaf extract of Parthenium hysterophorus but other crops like wheat and green gram, failure of seed germination was recorded only at $5 \%$ concentration of leaf extract. The Parthenium hysterophorus L. have potential to inhibit the seed germination and seedling emergence of different plants due to the presence of allelochemicals. So, in field condition, the incorporation of parthenium plants to the soil affects the growth and yield of succeeding crops. To decrease the impact of parthenin effect on crop, the removal of Parthenium plants before its flowering or before sowing of crop may be recommended, after further research.

\section{REFERENCES}

Batish D.R., Singh H.P., Pandher J.K. and Kohli R.K. 2005. Allelopathic Interference of Parthenium hysterophorus residues in soil. Allelopathy Journal, 15: 267-273.

Bhatt B.P., Chauhan D.S. and Todaria N.P., 1994. Effect of weed leachates on germination and radicle extension of some food crops. Indian Journal of Plant Physiology, 37: 177-179.

Dongre P.N. and Singh A.K., 2007. Inhibitory effects of weeds on growth of wheat seedlings. Allelopathy Journal, 20 (2): 387-394.

Dongre P.N., Singh A.K. and Chaubey K.S., 2004. Allelopathic effects of weed leaf leachates on seed germination of blackgram (Phaseolus mungo L.). Allelopathy Journal, 14(1): 65-70.

Dongre P.N., Chaubey K.S. and Singh A.K., 2010. Effects of leaf extracts of weeds on growth and yield of green gram. Allelopathy Journal, 25(1): 213-220.

Kanchan S.D., 1975. Growth inhibitors from Parthenium hysterophorus L. Current Science, 44: 358-259.
Kanchan S.D. and Jayachandra, 1979. Allelopathic effect of Parthenium hysterophorus L. I. Exudation of inhibitors through roots. Plant and Soil, 53: 2735 .

Qasem J.R. and Foy C.L., 2001. Weed Allelopathy, its ecological impacts and future prospects: a review. J. Crop. Prod., 4: 43-119.

Rajan L., 1973. Growth inhibitors from Parthenium hysterophorus L. Current Science, 42(20): 729730 .

Rajendiran K., 2005. Mitodepressive effects of aqueous extracts of Parthenium hysterophorus L. on Vigna radiata (L) Wilczek. Geobios., 32: $237-$ 240 .

Rashid H., Khan M.A., Amin A., Nawab K., Hussain N. and Bhowmik P.K., 2008. Effect of Parthenium hysterophorus L., root extracts on seed germination and growth of maize and barley. The Americas J. Plant Sci. Biotech., 2: 51-55.

Regina G.B., Reinhardtb C.F., Foxcroftc L.C. and Hurlea K., 2007. Residue allelopathy in Parthenium hysterophorus L.-Does parthenin play a leading role? Crop Protect, 26: 237-245.

Singh H.P., Batish D.R., Setia N. and Kohli R.K., 2005. Herbicidal activity of volatile oils from Eucalyptus citriodora against Parthenium hysterophorus L. Annal. App. Biol., 146: 89-94.

Swaminathan C., Rai R.S. and Sureshi K.K., 1990. Allelopathic effects of Parthenium hysterophorus L. on germination and seedling growth of a few multipurpose trees and arable crops. The International Tree Crops Journal, 143-150.

Tomaszewski M. and Thimann K.V., 1966. Interactions of phenolic acids, metallic ions and chelating agents on auxin induced growth. Plant Physiol. 41: 1443-1454.

Willis R.J., 1994. Terminology and trends in allelopathy. Allelopathy Journal, 1: 6-28. 